\title{
https://doi.org/10.46813/2020-130-111 \\ PECULIARITIES OF ELECTROMAGNETIC FILTER OPERATION IN PENNING SOURCE WITH METAL HYDRIDE CATHODE
}

\author{
I. Sereda, Ya. Hrechko, Ie. Babenko, A. Kashaba \\ V.N. Karazin Kharkiv National University, Kharkiv, Ukraine \\ E-mail: igorsereda@karazin.ua
}

The paper describes a method of negative hydrogen ions separation from axial flow of charged particles extracted from Penning discharge with a metal hydride cathode. For this purpose, an electromagnetic filter has been designed basing on numerical solution of motion equations of charged particles in the filter. The optimal parameters of the filter operation were determined for the effective registration of negative hydrogen ions extracted in axial direction. Performed calculations together with experimental verification shows that there are not more than $10 \%$ electrons in the registered $\mathrm{H}^{-}$current. This model could be applied for the interpretation of any experiments with $\mathrm{H}^{-}$ions separation from an axial flow of charged particles extracted from a source with cylindrical geometry.

PACS: $52.80 . \mathrm{Sm}$

\section{INTRODUCTION}

The metal hydride hydrogen activation increases the efficiency of negative $\mathrm{H}^{-}$ions formation by the mechanism of dissociative attachment in the plasma volume [1]. For the flux of accompanying electrons reduction negative ions are traditionally extracted across the magnetic field, for example, through an aperture in the anode, as it was realized in an Eller's-type source [2]. The source design with metal hydride cathode could be greatly simplified due to the discharge properties changing [3]. It appears that at high discharge voltages a flow of negatively charged particles including negative ions and electrons along with positive ions starts yielding along the external magnetic field [4]. Picking up the value of external magnetic field, electric supply and discharge dimensions one could achieve the situation when the current of positive ions will be much lower than the negative one.

In [4] an electromagnetic filter was proposed for the separation of $\mathrm{H}^{-}$ions in the axial flow. The methodology for calculating the filter parameters and the trajectory of charged particles according to the properties of the discharge [3] is given in [5]. But a change in discharge parameters, such as electrodes geometry, electrical supply and local injection of activated hydrogen from metal hydride cathode, impacts the axial flow of charged particles. In particular, the optimal parameters of the filter operation are changing. Thus, verification of experimental data requires additional calculations.

This work summarizes the results obtained earlier, demonstrates the influence of the electric potentials of the filter electrodes and the distribution of the magnetic field on the trajectories of charged particles for the effective registration of negative hydrogen ions extracted in axial direction.

\section{FILTER CONSTRUCTION}

A cathode unit with electromagnetic filter, which was created in [5] is shown in Fig. 1. It consists a copper cathode-reflector and a magnetic filter which includes a grid (1), electrons current collector (2), a coil of magnetic field (4) and a collector of negative ions (5). ISSN 1562-6016. BAHT. 2020. №6(130)

PROBLEMS OF ATOMIC SCIENCE AND TECHNOLOGY. 2020, № 6. Series: Plasma Physics (26), p. 111-114
The copper cathode-reflector (3) has got an aperture in the center $0.5 \mathrm{~cm}$ in diameter for charged particles extraction. The distance between the cathode-reflector of Penning cell (3), the grid (1) and the electron collector (2) were the same and were $0.4 \mathrm{~cm}$. The ion collector (5) was at the distance of $1.8 \mathrm{~cm}$ from the copper cathode-reflector (3). The cathodes and collectors were under ground potential. The grid (1) was supplied with positive potential for positive particles removing.

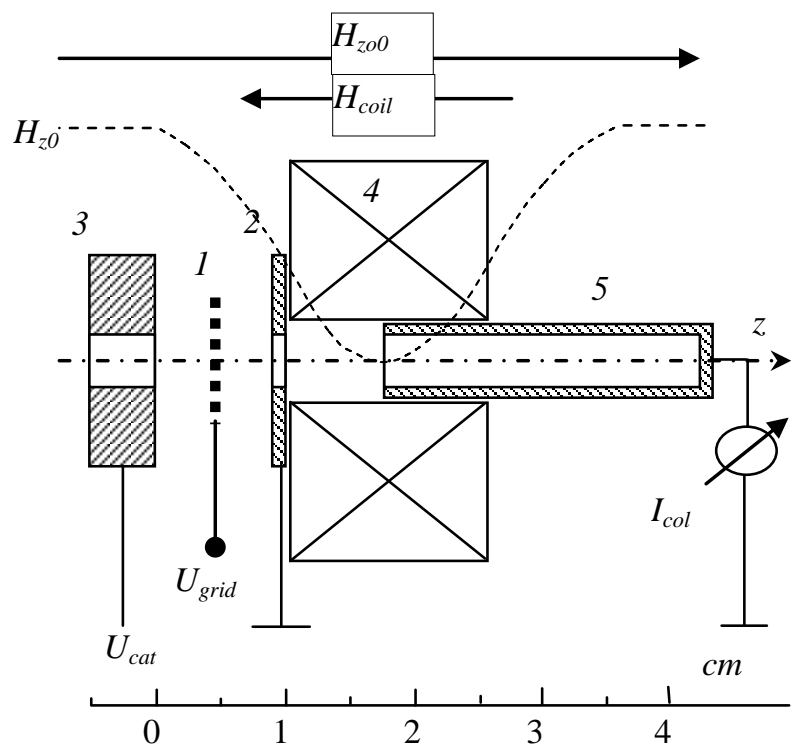

Fig. 1. The cathode unit with electromagnetic filter: 1 - retarding grid; 2 - copper cathode-reflector with an aperture; 3 -electrons collector; 4 - coil of the filter magnetic field; $5-H$ ion collector

The whole electrodes system was placed in external uniform longitudinal magnetic field $H_{z o 0}$ with intensity that could be changed in the range of $H_{z o 0}=0 \ldots 0.1 \mathrm{~T}$. The filter construction provides an idea for the creation of reverse magnetic field in the gap between the cathode (3) and the collector (5) to deflect electrons, but not impact on $\mathrm{H}^{-}$ions. The unit design also assumed that magnetic field of the filter $H_{\text {coil }}$ do not distorted the uniform magnetic field $H_{z o 0}$ in the discharge cell. 


\section{CALCULATION METHOD}

Taking into account the configuration of the electrodes, which ensures the registration of only the paraxial group of particles, the equation of motion can be obtained in the paraxial approximation in similar way as it was done in [6]:

$$
\frac{d^{2} r}{d z^{2}}+\frac{1}{2} \frac{\varphi_{o}^{\prime}}{\varphi_{o}} \frac{d r}{d z}-\frac{q}{8 m c^{2}} \frac{r H_{z 0}^{2}}{\varphi_{o}}\left(1-\left(\frac{r_{0}^{2} H_{z o 0}}{r^{2} H_{z 0}}\right)^{2}\right)=0,
$$

where $\varphi_{o}=\varphi(0, z)$ is a potential on the discharge axis relative to the potential of the particle creation point $\varphi_{o}=\varphi(0, z)$, which depends on electric potential of the cathode (3) (see Fig. 1). $\varphi_{o 0}=0$ in case of ground potential on the cathode. $r_{0}$ is the radius of the particle's entry into the gap. To solve equation non-uniform magnetic and electric fields in the investigated gap must be specified. The profile of magnetic field in equation depends on two variables: $H_{z o 0}=H\left(0, z_{0}\right)$ is a magnetic field on the axis at the emitter point $z_{0}$. The fixed value of $0.06,0.08$, and $0.1 \mathrm{~T}$ were selected for $H_{z o 0}$. $H_{z 0}=H(0, z)$ is the profile of inhomogeneous magnetic field on the axis in the cathode-collector gap, which is created by the counter-switching of the coils on the axis at an arbitrary point.

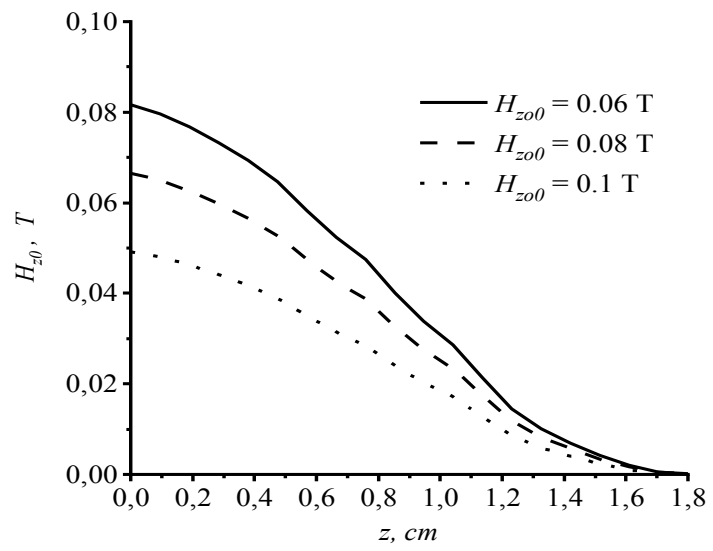

Fig. 2. The magnetic field distribution in the gap cathode $(z=0 \mathrm{~cm})$-collector $(z=1.8 \mathrm{~cm})$

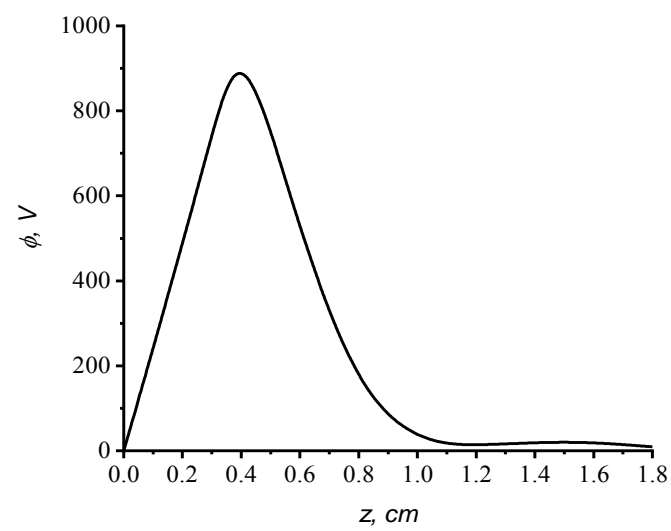

Fig. 3. The electrical potential distribution in the gap cathode $(z=0 \mathrm{~cm})$-collector $(z=1.8 \mathrm{~cm})$

The profiles $H_{z 0}$ (Fig. 2) and $\varphi_{o}=\varphi(0, z)$ (Fig. 3) were calculated in the program femm 4.0 basing on the geometric dimensions of the cathode unit, the potentials of the electrodes and the coil current.
Equation was obtained under the assumption of a slowly varied electric and magnetic fields in longitudinal direction.

The solution of the eq. was carried out numerically by the fourth-order Runge-Kutta method and the result is a paraxial trajectory equation in meridian plane $r=r(z)$.

\section{RESULTS AND DISCUSSION}

The result of the numerical solution is the dependence of the particle position $r(z)$ at a certain value of the longitudinal coordinate $z$ in the cathode-collector gap. These results are presented in the Fig. 4. The position and size of the coil and the collector correspond to the figure scale. In our calculations, the position $z=0.0 \mathrm{~cm}$ corresponds to the cathode edge and $z=1.8 \mathrm{~cm}-$ to the collector edge.

The presented results demonstrate the important role of the filter grid (1) (see Fig. 1). The supply of a positive potential $U_{\text {grid }}$ to the grid, in addition to the reflection of positive $\mathrm{H}_{2}{ }^{+}$ions, also accelerates the negative component of the flow. Thus, it is possible to separate the trajectories of electrons and $\mathrm{H}^{-}$ions using the transverse component of the magnetic field.

Taking into account that in some modes of the discharge operation only negative particles yield in the longitudinal direction $[3,7]$, it would be a mistake to completely remove the grid (1). This is due to the ratio of the energies of electrons and $\mathrm{H}^{-}$ions which is approximately equal to the root of the ratio of their masses. Thus, the magnetic field will deflect them at close angles and separation will not be effective. The oscillating behavior of the curves here is apparently related to the projection of the Larmor motion of the low energy particles on the $r(z)$ plane.

Otherwise the reversal magnetic field has a little effect on the trajectory of $\mathrm{H}^{-}$ions, whereas, electron trajectories significantly curves, and at the value of total magnetic field $H_{z 0}=0$ at $z=1.8 \mathrm{~cm}$ (collector edge) the electrons are diverted.

It should be noted that the end of electron trajectories essentially depends on the initial value of the constant $r_{0}$, where $r_{0}$ is the radius of electron entry in the gap. For example, at zero magnetic field on the collector edge and $r_{0}>0.08 \mathrm{~cm}$ all the electrons are diverted. Accordingly, electrons that moves strictly in the coaxial tube $0.16 \mathrm{~cm}$ in diameter slightly diverted by magnetic field and registered by the ion's collector. In other words, only electrons, which have an entrance radius $r_{0} \leq 0.08 \mathrm{~cm}$ pass through. The magnetic field in the gap has weak effect on them. The rest main part of electrons is successfully diverted. Estimates shown that the current of passed electrons should be an order of magnitude smaller than the diverted one. In the same time the trajectories of ions had been little effect magnetic field on.

Thus, when the electromagnetic field operates with the required parameters, the measured current on collector (5) could be associated with $\mathrm{H}^{-}$ions. In case of the filter is switched off $\left(H_{\text {coil }}=0\right.$ and $\left.\varphi_{0}=0\right)$ one can measure the total current of charged particles included $\mathrm{H}_{2}{ }^{+}, \mathrm{H}^{-}, \mathrm{e}^{-}$outgoing in axial direction. 


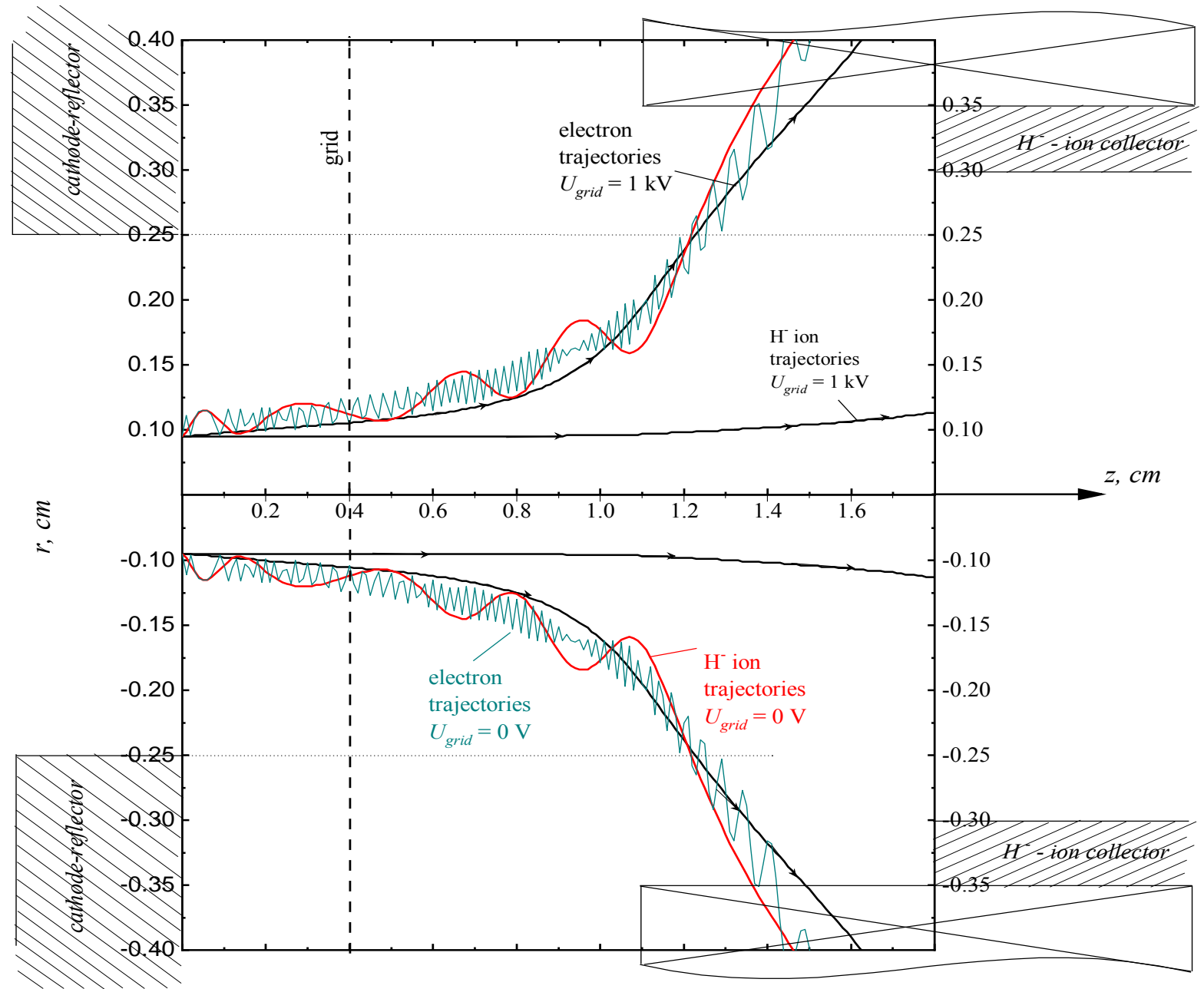

Fig. 4. The trajectories of electrons and negative ions in the gap cathode $(z=0 \mathrm{~cm})$-collector $(z=1.8 \mathrm{~cm})$

A positive potential supply to the cathode still weakly affects the ion trajectories, but the electrons, at the same time, are deflected by a larger angle by the magnetic field. So, it even further increases the filter efficiency.

The electromagnetic filter operation as a part of a Penning cell with metal hydride cathode is shown in Fig. 5. Here is a typical dependence of the collector current $I_{c o l}$ depending on the ratio of the external magnetic field $H_{z o 0}=0.1 \mathrm{~T}$ to the magnetic field $H_{\text {coil }}$, which is created by the filter coil. The value of $H_{z o 0} / H_{c o i l}=1$ corresponds to the calculated trajectories of charged particles shown in Fig. 4 (black curves).

The discharge voltage $U_{d}=5 \mathrm{kV}$, the pressure $p=5 \cdot 10^{-6}$ Torr and the grid potential $U_{\text {grid }}=1 \mathrm{kV}$ were selected on the base of the discharge features and corresponded to the mode when a negative axial current of charged particles was registered [4].

One can see from the figure, an increase of $H_{\text {coil }}$ causes the growth of transverse component of the magnetic field, which deflects the electrons. According to the calculations the ratio $H_{z o 0} / H_{\text {coil }}=1$ is optimal for electron diverting. However, the experiment showed that this value can lie in the range from 0.6 to 1.1 (Fig. 5). The decrease of the current at $H_{z o 0} / H_{\text {coil }}>1.1$ is hardly related to the deviation of negative ions, since in this case the magnetic field $H_{\text {coil }}$ will no longer be con- centrated only in the cathode-collector gap, but will penetrate into the plasma region and will distort the uniform magnetic field $H_{z o O}$ in the discharge cell.

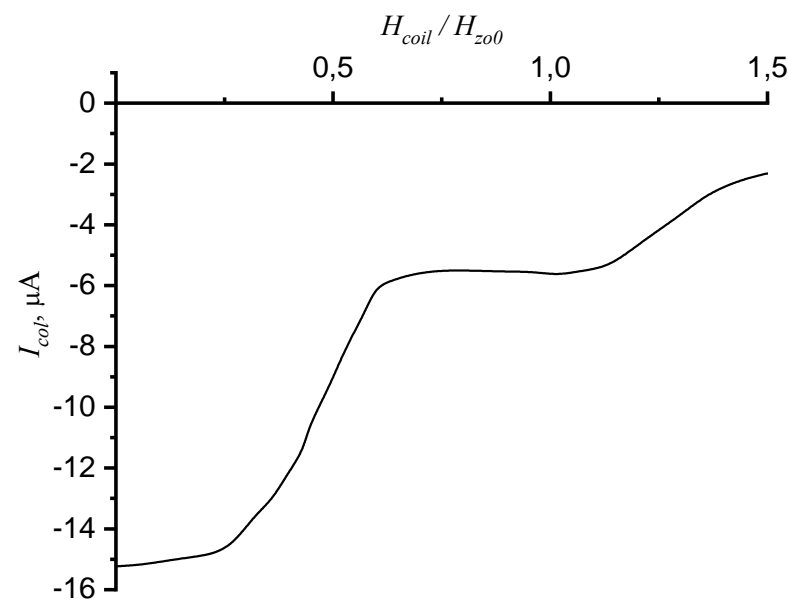

Fig. 5. The dependence of collector current $I_{\text {col }}$ on $H_{\text {coil }} / H_{z o 0}\left(H_{z o 0}=0.1 \mathrm{~T}, U_{d}=5 \mathrm{kV}, U_{\text {grid }}=1 \mathrm{kV}\right.$, $p=5 \cdot 10^{-6}$ Torr)

Thus, the obtained data are in good agreement with the calculation. 


\section{CONCLUSIONS}

The separation of $\mathrm{H}^{-}$ions flow from electrons and positive ions could be made with electro-magnetic filter. Positive ions are retarded by electric field of the grid and electrons are diverted by magnetic field. Performed calculations together with experimental verification shows that there are not more than $10 \%$ electrons in the registered $\mathrm{H}^{-}$current. At the same time, electrical field of the grid fully reflects positive ions. Summarizing the numerous calculations expands the range of the best external parameters for the efficient separation of $\mathrm{H}^{-}$ ions from the axial flow of charged particles. This model could be applied for the interpretation of any experiments with $\mathrm{H}^{-}$ions separation from an axial flow of charged particles extracted from a source with cylindrical geometry.

\section{REFERENCES}

1. I. Sereda, A. Tseluyko, N. Azarenkov. The Application of Metal Hydride Based on Zr-V Alloy in Hydrogen Plasma // Patrick C. Dam, editor. Hydrides: Types, Bonds and Applications, New York: «Nova Science Publishers Inc». 2018, p. 149-192.
2. M. Bacal, M. Wada. Negative hydrogen ion production mechanisms // Appl. Phys. Rev. 2015, v. 2, p. 021305.

3. I.V. Borgun, D.L. Ryabchikov, I.N. Sereda, A.F. Tseluyko. PIG charged particle source with hydrogen supply from a metal-hydride cathode // J. Phys. Conf. Ser. 2014, v. 514, p. 012051.

4. I. Sereda, A. Tseluyko, D. Ryabchikov, Ya. Hrechko, N. Azarenkov. Effect of metal-hydride hydrogen activation on longitudinal yield of negative ions from PIG // International Journal of Hydrogen Energy. 2017, v. 42/34, p. 21866-21870.

5. I.N. Sereda, A.F. Tseluyko, D.L. Ryabchikov, Ya.O. Hrechko, A. Krupka. Electromagnetic filter for $\mathrm{H}$ - separation from PIG with metal hydride cathode // Problems of Atomic Sci. and Tech. Series «Plasma Electronics and New Methods of Acceleration» (116). 2018, № 4, p. 282-284.

6. Brown Ian G. The physics and technology of ion sources / John Wiley \& Sons: «New York», 1989, p. 85-87.

7. I.N. Sereda, Ya.O. Hrechko, D.L. Ryabchikov, A.F. Tseluyko, N.A. Azarenkov. The increasing of $\mathrm{H}^{-}$current from Penning ion source with electrically biased metal hydride cathode // Vacuum. 2019, v. 162, p. 163-167.

Article received 28.09.2020

\title{
ОСОБЕННОСТИ РАБОТЫ ЭЛЕКТРОМАГНИТНОГО ФИЛЬТРА В ПЕННИНГОВСКОМ ИСТОЧНИКЕ С МЕТАЛЛОГИДРИДНЫМ КАТОДОМ
}

\author{
И. Середа, Я. Гречко, Е. Бабенко, А. Качаба
}

\begin{abstract}
Описан метод сепарации отрицательных ионов водорода из аксиального потока заряженных частиц, выходящих из разряда Пеннинга с металлогидридным катодом. С этой целью на основе численного решения уравнения движения заряженных частиц разработан электромагнитный фильтр. Определены оптимальные параметры работы фильтра для эффективной регистрации отрицательных ионов водорода, выходящих в аксиальном направлении. Проделанные расчеты вместе с экспериментальной проверкой показали, что не более $10 \%$ электронов содержится в регистрируемом токе отрицательных ионов водорода. Данная модель может быть применена для интерпретации любых экспериментов по сепарации ионов $\mathrm{H}^{-}$из аксиального потока заряженных частиц, извлекаемых из источника с цилиндрической геометрией.
\end{abstract}

\section{ОСОБЛИВОСТІ РОБОТИ ЕЛЕКТРОМАГНІТНОГО ФІЛЬТРА В ПЕННІНГОВСЬКОМУ ДЖЕРЕЛІ 3 МЕТАЛОГІДРИДНИМ КАТОДОМ}

\section{I. Середа, Я. Гречко, С. Бабенко, А. Кашаба}

\footnotetext{
Описаний метод сепарації негативних іонів водню з аксіального потоку заряджених частинок, що виходять із розряду Пеннінга з металогідридним катодом. 3 цією метою на основі чисельного рішення рівняння руху заряджених частинок був розроблений електромагнітний фільтр. Визначено оптимальні параметри роботи фільтра для ефективної реєстрації негативних іонів водню, що виходять в аксіальному напрямку. Зроблені розрахунки разом з експериментальною перевіркою показали, що не більше 10\% електронів реєструються в струмі негативних іонів водню. Ця модель може бути застосована для інтерпретації будь-яких експериментів по сепарації іонів $\mathrm{H}^{-}$з аксіального потоку заряджених частинок, що витягаються 3 джерела, що має циліндричну геометрію.
} 